\title{
Ametoctradin: a new fungicide for potato late blight control
}

\author{
Ametoctradina: um novo fungicida para controle da requeima da batata
Jesus Guerino Töfoli1 ${ }^{*}$, Ricardo José Domingues', Walter Jacobelis Jr.², Marina Pacheco Lombardi Tortolo²

\begin{abstract}
Late blight (Phytophthora infestans) is among the most important and destructive diseases in potato cultivation. Aiming to evaluate the efficacy of the new fungicide ametoctradin, mixed with dimethomorph and metiram, an experiment was carried out in commercial potato crops (Ágata cultivar) in Pilar do Sul, Sáo Paulo state, Brazil, during the growing season in 2013. A randomized block design was used, with 4 replications, on plots of $15 \mathrm{~m}^{2}$. Applications were carried out using a backpack sprayer with a spray-bar under 3 bar of constant pressure. The application volume varied from $300 \mathrm{~L}$ to $600 \mathrm{~L}^{\mathrm{L}} \mathrm{ha}^{-1}$ based on crop development. The variables evaluated were leaf severity ( 0 to $100 \%$ ), area under the disease progress curve, and yield. Ametoctradin + dimethomorph (1.25 L.ha $\left.{ }^{-1}\right)$ provided significant control of late blight, exceeding benthiavalicarb + fluazinam, dimethomorph + metiram, dimethomorph + pyraclostrobin, cymoxanil + mancozeb, metalaxyl-M + mancozeb, ametoctradin + metiram, and pyraclostrobin + metiram, although similar to ametoctradin + dimethomorph (1.00 L.ha $\left.{ }^{-1}\right)$, fluopicolide + propamocarb, and fenamidone + propamocarb. Ametoctradin + metiram resulted in moderate control, which was always similar to the standard. Ametoctradin and its associations represent a new alternative for the management of potato late blight.
\end{abstract}

KEYWORDS: Solanum tuberosum L.; Phytophthora infestans; pyrimidylamine; chemical control.
RESUMO: A requeima (Phytophthora infestans) é uma das mais importantes e destrutivas doenças da cultura da batata. Com o objetivo de avaliar a ação do novo fungicida ametoctradina em mistura com dimetomorfe e metiram, foi realizado um experimento em cultivo comercial de batata (cultivar Ágata), localizado em Pilar do Sul, São Paulo, na safra 2013. O delineamento experimental utilizado foi o de blocos ao acaso, com 4 repetiçôes, sendo cada parcela de $15 \mathrm{~m}^{2}$. As aplicaçôes foram realizadas com um pulverizador costal, munido de barra de aplicação e pressão constante de 3 Bar. O volume de aplicação variou de 300 a 600 L.ha $^{-1}$ em função do desenvolvimento da cultura. As variáveis avaliadas foram: severidade em folhas (0 a 100\%), área abaixo da curva de progresso da doença e produtividade. Ametoctradina + dimetomorfe (1,25 L.ha-1) proporcionou controle significativo da requeima, sendo superior a bentiavalicarbe + fluazinam, dimetomorfe + metiram, dimetomorfe + piraclostrobina, cimoxanil + mancozebe, metalaxil- $M+$ mancozebe, ametoctradina + metiram, piraclostrobina + metiram e semelhante a ametoctradina + dimetomorfe $\left(1,00\right.$ L.ha $\left.{ }^{-1}\right)$, fluopicolide + propamocarbe e fenamidona + propamocarbe. Ametoctradina + metiram apresentou comportamento intermediário, sendo sempre similar aos padrôes. Ametoctradina e suas associações representam uma nova alternativa para o manejo da requeima na cultura da batata.

PALAVRAS-CHAVE: Solanum tuberosum L.; Phytophthora infestans; piridilamina; controle químico. 
Considered the great "buried treasure" of the Andean peoples, the potato (Solanum tuberosum) transformed habits, cultures, and customs throughout the world thanks to its excellence as a food source, its adaptability, and its great production potential. Surpassed only by rice and wheat, this Solanaceae is an important source of carbohydrates, phosphorous, potassium, B-complex vitamins, vitamin $\mathrm{C}$, high quality protein, dietary fiber, and other nutrients, and can be consumed raw or processed in various ways.

Potato cultivation has great economic and social importance in Brazilian agriculture. Once considered an activity for small farmers, today, the potato's supply chain takes welldefined industrial characteristics. São Paulo state and the south of Minas Gerais state, in the Brazilian Southeast, as well as the states of Paraná and Rio Grande do Sul, in the South, are the main cultivation regions in Brazil, responsible for $90 \%$ of national production. New projects and production areas have arisen in Goiás and Bahia states, with noticeable effects to the national market. In 2015, Brazilian potato production was 3.7 million tons, occupying an area of $128,276 \mathrm{ha}$, and averaging a yield of 28.6 t.ha- $^{-1}$ (IBGE, 2016).

Late blight, caused by the Oomycota Phytophthora infestans, is considered one of the most important and destructive diseases in potato cultivation. Present in practically all production regions in the country, it drastically affects leaves, stems, petioles, and tubers. Among the factors that contribute the most to the appearance of severe late blight epidemics in Brazil, the most noteworthy are extensive planting of susceptible varieties, presence of the disease inoculum throughout the year, favorable climatic conditions, high dissemination capacity, and high capacity for inoculum production (Mizubuti, 2001; Dias; Iamauti, 2005, Töfoli et al., 2012).

Currently, integrated potato production programs have recommended the adoption of joint control measures for the management of late blight, such as the use of certified seed and resistant varieties; avoiding cultivation in wet areas; utilizing appropriate irrigation techniques, balanced fertilization, and crop rotation practices; eliminating crop residue; controlling weeds; and applying fungicides (STEVENSON et al.,2008; TöFOLI et al., 2013a).

In general, the varieties with the highest degree of acceptance in the Brazilian market are susceptible to late blight, which necessitates the use of fungicides for their management. Among the active ingredients registered, the most significant are products based on metalaxyl-M, dimethomorph, cymoxanil, fluopicolide, mandipropamid, and benthiavalicarb. Contact products belonging to classes of dithiocarbamates, chloronitriles, phthalonitriles, and copper formulations are also widely used, whether in isolated applications or in specifically formulated products (TöFoli et al., 2013b).

The fungicide ametoctradin is a new alternative for the control of Oomycetes. Belonging to a new class of pyrimidylamines (FRAC 45), it is characterized as being a powerful respiratory inhibitor of complex III, cytochrome bc at $\mathrm{Q}_{\mathrm{O}}$ site stigmatellin binding subsite (GolD et al., 2009; Merk et al., 2011,
FRAC, 2016). In $P$. infestans, it acts mainly on the formation, liberation, and motility of zoospores and the germination of cysts. Its novel mechanism of action allows it to function on strains of Oomycetes resistant to phenylamides (metalaxyl-M, benalaxyl), QoIs (pyraclostrobin, fenamidone, and famoxadone), and amides of carboxylic acid (dimethomorph, benthiavalicarb, and mandipropamid), allowing it to become an alternative for the control and management of resistance when mixed with other fungicides.

Considering the importance of introducing new chemicals for the management of late blight, the present study aimed to evaluate the control potential of ametoctradin mixed with dimethomorph and metiram, as compared to other fungicides available on the market.

The experiment was conducted in a commercial potato crop (Ágata cultivar) located in Pilar do Sul, São Paulo, Brazil, from July to October 2013.

The fungicides ( $\mathrm{kg}$ or $\mathrm{L}$ of commercial product (c.p.) per ha) tested were: dimethomorph + ametoctradin (1.00 and 1.25$)$, mandipropamid $(0.50)$, pyraclostrobin + metiram (3.00), dimethomorph + metiram $(0.45+0.30)$, metalaxyl$\mathrm{M}+$ mancozeb (2.50), cymoxanil + mancozeb (2.00), benthiavalicarb + fluazinam $(0.50)$, fenamidone + propamocarb (2.00), fluopicolide + propamocarb (1.25), ametoctradin + metiram (2.50), and dimethomorph + pyraclostrobin (2.00).

The experiment utilized a randomized block design with 13 treatments and 4 replications, each plot being $15 \mathrm{~m}^{2}$ in area.

Spraying was carried out preventively, beginning 35 days after planting (DAP), using a backpack sprayer with constant pressure ( $3 \mathrm{bar}$ ) and spray bar with 5 conical nozzles (XR110.015), spaced at $0.5 \mathrm{~m}$ intervals. The distance between the spray bar and the target area during application was approx-

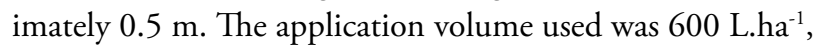
totaling 7 applications at 7 day-intervals.

The characteristics evaluated in the experiment were:

1. leaf severity;

2. area under the disease progress curve (AUDPC) of the blight; and

3. total yield.

Leaf severity was evaluated as the percentage of leaf area affected by late blight from the appearance of the first symptoms (0 to $100 \%$ ) using the scale proposed by Cruickshank et al., (1982). Five evaluations were carried out at 5 to 7 -day intervals, considering all plants in the central $10 \mathrm{~m}^{2}$ of each plot. The leaf severity values were used to calculate the AUDPC in accordance with the method proposed by CAmpbell; Madden (1990). The AUDPC values were standardized, dividing each value by the number of days of the blight outbreak. The variable referring to the production of tubers was the total yield $\left(\right.$ ton.ha $\left.^{-1}\right)$.

Statistical analysis was carried out using the comparison between the average areas under the disease progression curves by the Tukey test at $5 \%$ probability. For leaf severity and progress of the disease, the data were square root transformed prior to analysis. 
The occurrence of favorable conditions allowed the blight to reach a high severity, thus giving significance to the reduction of the disease in the plots treated with the tested fungicides.

In the evaluations performed from October 1 to 8, 2013, all fungicides significantly reduced the severity of the blight in a similar manner. From October 15 to 22, 2013, ametoctradin + dimethomorph (1.25 L.ha-1) promoted the lowest percentages of leaf area affected, showing more efficacy than benthiavalicarb + fluazinam, dimethomorph + metiram, dimethomorph + pyraclostrobin, cymoxanil + mancozeb, metalaxyl-M + mancozeb, ametoctradin + metiram, and pyraclostrobin + metiram, although similar to the other treatments (Table 1 and Figs. 1 and 2).

Table 1. Severity of late blight in potato plants, Ágata cultivar, treated with fungicides at 5, 12, and 19 days after the last application. Pilar do Sul, São Paulo, 2013.

\begin{tabular}{lccccc} 
& $\begin{array}{c}\text { Doses } \\
\text { (L or kg c.p./ha) }\end{array}$ & $10 / 01 / 13$ & $\begin{array}{c}\text { 5 DALA } \\
10 / 08 / 13\end{array}$ & $\begin{array}{c}\text { 12 DALA } \\
10 / 15 / 13\end{array}$ & $\begin{array}{c}\text { 19 DALA } \\
10 / 22 / 13\end{array}$ \\
\hline Control & - & 29.00 & 70.00 & $98.00^{\text {a }}$ & $100.00^{\text {a }}$ \\
\hline Ametoctradin + dimethomorph & 1.00 & 0.33 & 0.50 & $2.50^{\text {cde }}$ & $4.30^{\text {fg }}$ \\
\hline Ametoctradin + dimethomorph & 1.25 & - & - & $0.80^{\mathrm{e}}$ & $3.50^{\mathrm{g}}$ \\
\hline Fluopicolide + propamocarb & 1.25 & - & 0.50 & $1.80^{\text {de }}$ & $3.00^{\text {g }}$ \\
\hline Benthiavalicarb + fluazinam & 0.50 & - & 2.00 & $7.00^{\text {bc }}$ & $47.50^{\text {b }}$ \\
\hline Dimethomorph + metiram & $0.45+0.30$ & - & 0.50 & $4.80^{\text {bcd }}$ & $15.00^{\text {cde }}$ \\
\hline Dimethomorph + pyraclostrobin & 2.00 & - & 0.50 & $4.55^{\text {bcd }}$ & $12.75^{\text {cdef }}$ \\
\hline Cymoxanil + mancozeb & 2.00 & 0.50 & 1.80 & $6.30^{\text {bc }}$ & $21.30^{c}$ \\
\hline Mandipropamid & 0.50 & - & 1.00 & $3.30^{\text {bcde }}$ & $7.00^{\text {defg }}$ \\
\hline Metalaxyl-m + mancozeb & 2.50 & 0.33 & 2.75 & $8.00^{b}$ & $16.30^{\text {cd }}$ \\
\hline Fenamidone + propamocarb & 2.00 & - & 0.50 & $2.50^{\text {cde }}$ & $5.80^{\text {ffg }}$ \\
\hline Ametoctradin + metiram & 2.50 & - & 1.80 & $4.30^{\text {bcd }}$ & $11.30^{\text {cdef }}$ \\
\hline Pyraclostrobin + metiram & 3.00 & 0.33 & 2.00 & $5.30^{\text {bcd }}$ & $16.00^{\text {cde }}$ \\
\hline CV (\%) & & & & 17.99 & 16.38 \\
\hline
\end{tabular}

DALA: days after the last application; CV: coefficient of variation. Averages followed by the same letter do not differ statistically among themselves using the Tukey test at $5 \%$ probability.

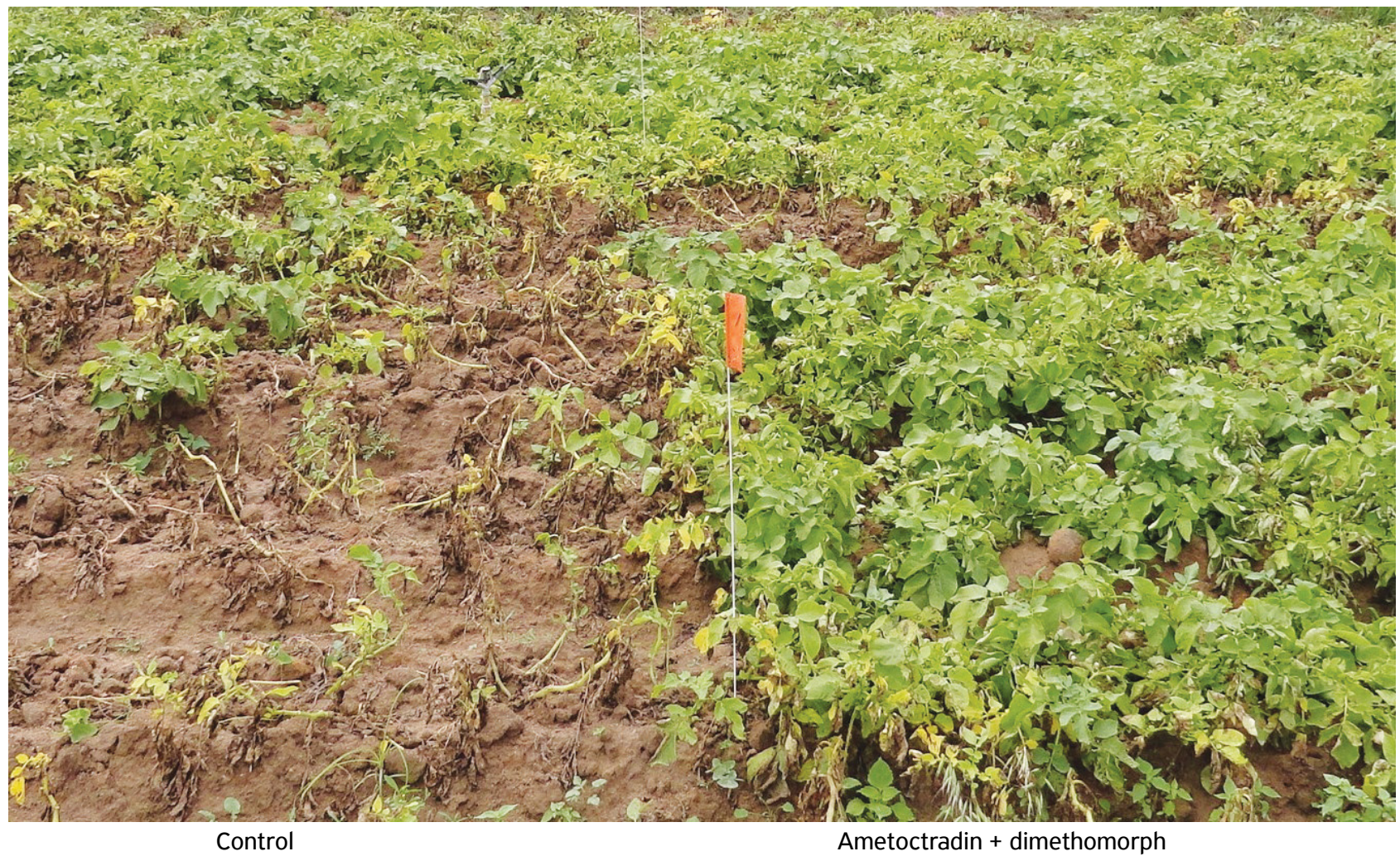

Figure 1. Severity of late blight in potato (Ágata cultivar) in plots not treated and treated with ametoctradin + dimethomorph (1.25 L.ha ${ }^{-1}$ ). Pilar do Sul, São Paulo, Brazil, 2013. 
As to the progress of the blight, the best results were also observed in the plots treated with the fungicide ametoctradin + dimethomorph (1.25 kg.ha- $\left.{ }^{-1}\right)$, which were similar to the ametoctradin + dimethomorph (1.00 kg.ha-1 $)$, fluopicolide + propamocarb, and fenamidone + propamocarb treatments, and superior to the other treatments (Fig. 3). Ametoctradin + metiram resulted in moderate performance for the criteria of blight severity and progression, which did not differ from the standard.

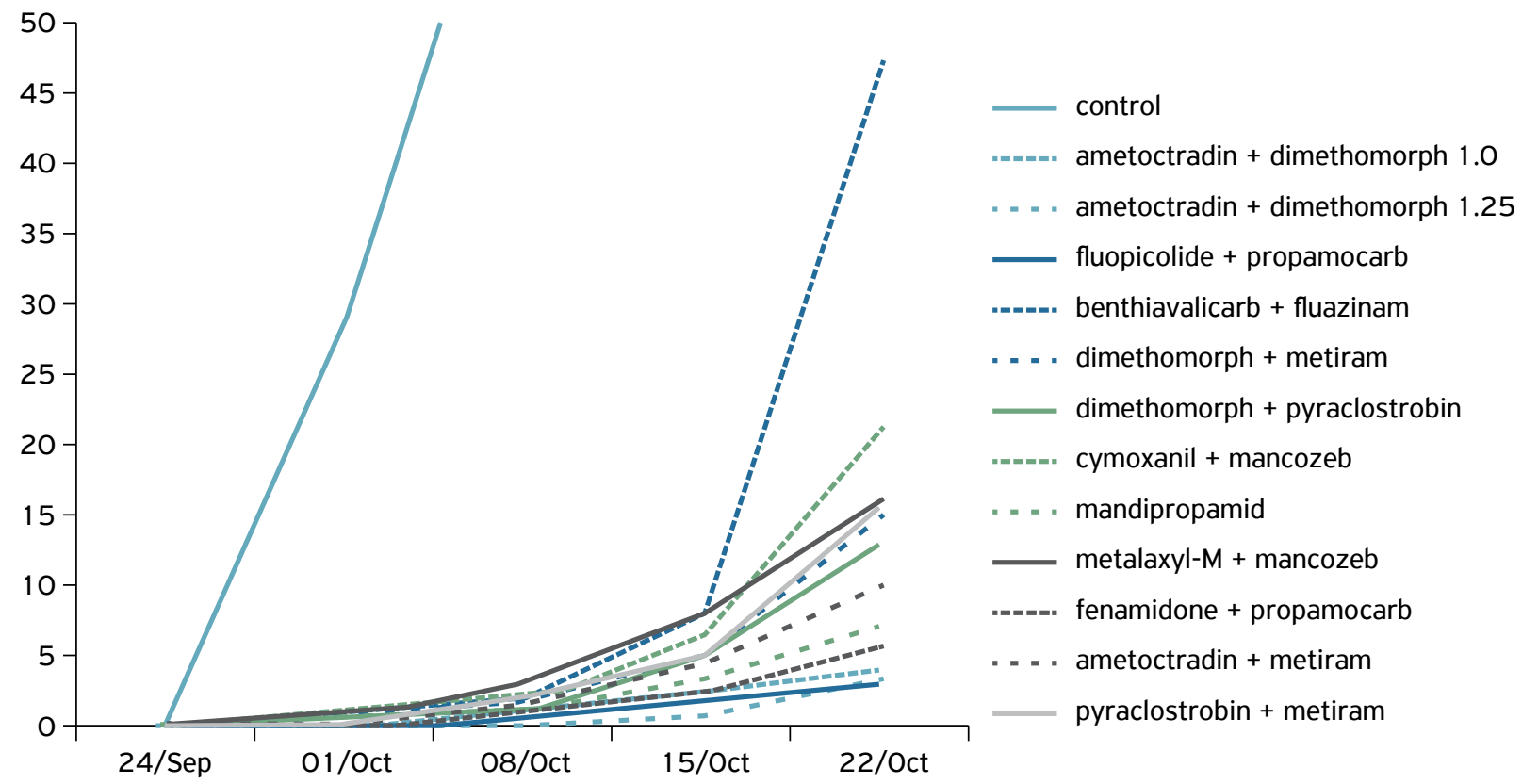

Figure 2. Evolution of late blight in potato plants (cultivar Ágata) treated with fungicides. Pilar do Sul, São Paulo, Brazil, 2013. Leaf severity (0 to $100 \%$ ) of leaf area affected.

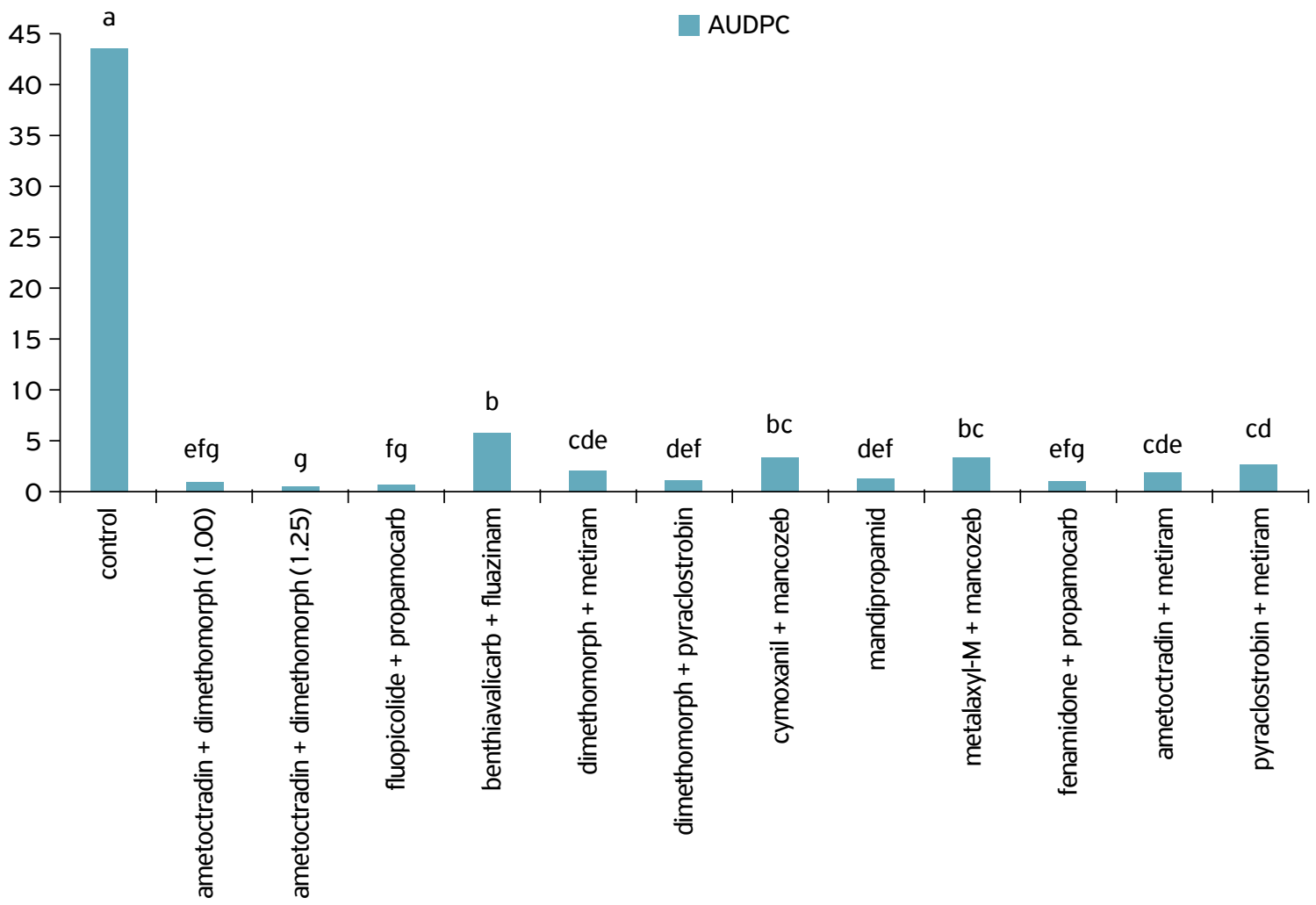


Ametoctradin + dimethomorph (1.25 L.ha $\left.{ }^{-1}\right)$ led to a significant increase in yield and was superior to benthiavalicarb + fluazinam, although similar to the other treatments (Fig. 4). In this experiment, the treatments based on benthiavalicarb + fluazinam, dimethomorph + metiram, ametoctradin + metiram, metalaxyl-M + mancozeb, and cymoxanil + mancozeb did not differ from the control for this criterion.

The tested treatments did not cause phytotoxic symptoms in the potato crop in the prevailing conditions of the experiment.

The positive results observed in this study for ametoctradin mixed with dimethomorph and metiram in late blight control are also highlighted by Reimann et al. (2010), TegGe et al. (2012) and Töfolı et al. (2016). Similarly, Töfolı et al.
(2016) also emphasized the high potential of these mixtures to promote yield increases in potato fields affected by late blight.

Apart from ametoctradin having a distinct mechanism of action and a compatible toxicological profile, it is important to highlight that this fungicide has a high degree of stability and affinity with waxy layers of the leaf surface, which allows high levels of protective, curative, and anti-sporulant action; longer-lasting protection; and rain resistance (GolD et al., 2009; Merk et al., 2011, Töғoli et al., 2012, Töғoli et al. 2014).

Given the technological innovation presented by the new chemical and the results obtained in this study, it is concluded that ametoctradin and associated products are effective alternatives for the management of late blight in potato crops.

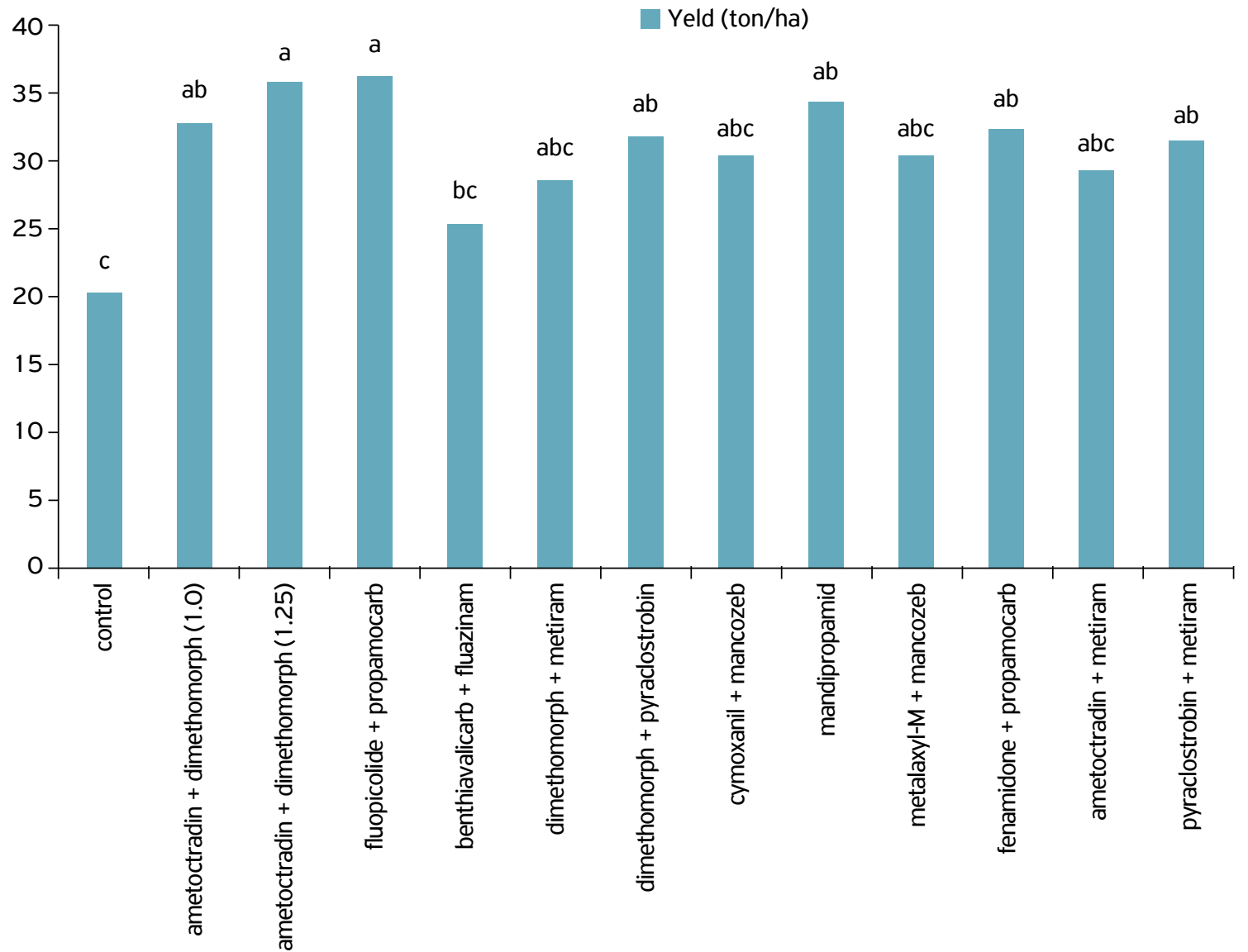

Averages followed by the same letter do not differ statistically among themselves using the Tukey test at 5\% probability. CV (\%); 10,24 .

Figure 4. Yield (ton/ha) of potato plants (cultivar Ágata) treated with fungicides. Pilar do Sul, São Paulo, Brazil, 2013.

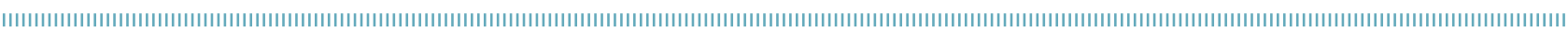

\section{REFERENCES}

CAMPBELL, C.L.; MADDEN, L.V. Introduction to plant disease epidemiology. New York: Wiley, 1990.

CRUICKSHANK, G.; STEWART, H.E.; WASTIE, R.L. An illustrated assessment key for foliage blight of potatoes. Potato Research, Wageningen, v.25, n.2, p.213-214, 1982.

DIAS, J.A.C.; IAMAUTI, M.T. Doenças da Batateira (Solanum tuberosum.). In: KIMATI, H.; AMORIN, L.; REZENDE, J.A.M.;
BERgAMIN FILHO, A.; CAMARGO, L.E.A. (Eds.). Manual de Fitopatologia: doenças das plantas cultivadas. 4 ed. São Paulo: Ceres, 2005. v.2, Cap.16, p.119-142.

FRAC. Fungicide resistance action commitee. FRAC code list 2016: Fungicides sorted by mode of action (including FRAC Code numbering). 2010. Available from: <http://www.frac.info/docs/ default-source/publications/frac-code-list/frac-code-list-2016. pdf?sfvrsn=2>. Accessed on: 21 jun. 2016. 
GOLD, R.; SCHERER, M.; RETHER, J.; SPEAKMAN, J.; NAVÉ, B.; LEVY, T.; STORER, R.; MARRIS, D. INITIUM ${ }^{\circledR}$ : an innovative fungicide of a new chemical class for the control of oomycetes. In: BCPC CONGRESS, 2009, Glasgow. Proceedings. Glasgow: BCPC, 2009. p.1-6.

IBGE. INSTITUTO BRASILEIRO DE GEOGRAFIA E ESTATÍSTICA. Disponível em: http://www.ibge.gov.br. Acesso em: 20 fev. 2016.

MERK, M.; GOLD, R.E.; SCHIFFER, H.; LEVY, T.; FRECHEN, T.; SARAMAGO, J. Initium ${ }^{\circledR}$ : a new innovative fungicide of a new chemical class for the control of late blight and downy mildews diseases. Acta Horticulturae, n.917, p.143-148, 2011. Available from: <http://www.actahort. org/books/917/917_18.htm>. Accessed on: 21 jun. 2016.

MIZUBUTI,E.S.G. Requeima ou mela da batata e tomate. In: LUZ, E.D.M.N.; SANTOS, A.F.; MATSUOKA, K.; BEZERRA, J.L. Doenças causadas por Phytophthora no Brasil. Campinas: Livraria Rural, 2001. p.100-174.

REIMANN, S.; JILDERDA, K.; GERBER, M.; TEGGE, V.; KLAPPACH, K. Initium ${ }^{\circledR}$ based products for the control of Phytophthora infestans in potatoes. PPO-Special Report, Arras, n.14, p.95-100, 2010.

STEVENSON, W.; KIRK, W.; ATALLAH, Z.K. Managing foliar disease: early blight, late blight and white mold. In: JOHNSON, D.A. (Ed.). Potato health management. St. Paul: APS, 2008. p.209-222.

TEGGE, V.; ERVEN, T.; KIERS, E.; KRUTS, M.; MURRAY, A.; BRIX H.D. Recommendations and field performance of Initium ${ }^{\circledR}$ based products against Phytophthora infestans in potato. PPO-Special Report, St Petersburg, n.15, p.119-122, 2012.
TÖFOLI, J.G.; DOMINGUES, R.J.; FERRARI, J.T.; NOGUEIRA, E.M.C. Doenças fúngicas da cultura da batata: Sintomas, etiologia e manejo. Biológico, São Paulo, v.74, n. 1, p.63-74, 2012.

TÖFOLI, J.G.; MELO, P.C.T.; DOMINGUES, R.J. Ação protetora, residual, curativa e anti-esporulante de fungicidas no controle da requeima e da pinta preta da batata em condições controladas. Arquivos do Instituto Biológico, São Paulo, v.79, n.2, p.209221,2012

TÖFOLI, J.G.; MELO, P.C.T.; DOMINGUES, R.J.; FERRARI, J.T. Requeima e pinta preta na cultura da batata: importância, características e manejo sustentável. Biológico, São Paulo, v.75, n. 1, p.33-40, 2013 a.

TÖFOLI, J.G.; MELO, P.C.T.; DOMINGUES, R.J.; FERRARI, J.T. Controle da requeima e pinta preta da batata por fungicidas: conceitos, evolução e uso integrado. Biológico, São Paulo, v.75, n. 1, p.41-52, $2013 \mathrm{~b}$.

TÖFOLI, J.G.; DOMINGUES, R.J.; MELO, P.C.T.; FERRARI, J.T. Effect of simulated rain on the efficiency of fungicides in potato late blight and early blight control. Semina: Ciências Agrárias, Londrina, v.35, n.6, p.2977-2990, 2014.

TÖFOLI, J.G.; MELO, P.C.T.; DOMINGUES, R.J. Controle da requeima e pinta preta da batata por fungicidas e seu reflexo sobre a produtividade e a qualidade de tubérculos. Arquivos do Instituto Biológico, v.83, 1-12, e 1172013, 2016. 